\title{
牛に対する腎生検の 影響
}

\author{
杉原聡介* 其田三夫* 高橋清志* 黒沢 隆* \\ （昭和 63 年 4 月 15 日受理）
}

\author{
Influence of Renal Biopsy on Cattle \\ Sōsuke Suglhara (School of Veterinary Medicine, Rakuno Gakuen University, \\ Ebetu, Hokkaido 069), Mitsuo Sonoda, Kiyoshi Takahashi \\ and Takashi Kurosawa
}

SUMMARY

Percutaneous renal biopsies were carried out on 5 normal and 13 diseased cows. The side effects and diagnostic significance of this method were evaluated.

1) Macroscopic hematuria observed after the surgery in 18 cases disappeared within 90 minutes and microscopic hematuria disappeared within 180 minutes.

2) The sizes of the pieces of tissues obtained by the method were about $5 \sim 20 \mathrm{~mm}$ long $\times 1 \sim 1.5$ $\mathrm{mm}$ width. Although they were slightly destroyed and reduced in size, they were useful for diagnosing interstitial nephritis and amyloidosis.

3) In all 13 cases autopsied 1 to 10 days after biopsy, small, though not severe, hematomas were observed between the parenchymal tissue and capsules.

4) Abnormal findings due to the biopsy were not observed except hematuria mentioned above by the clinical and hematological examinations.

From the results obtained, it may be suggested that percutaneous renal biopsy is a simple, safe and useful diagnostic method in the bovine practice.

\section{要約}

正常牛 5 例括よび病牛 13 例に対し, 経皮的腎生検を行い, 牛体への影響について検討し, 以下 の成績が得られた.

1）供試牛 18 例で術後にみられた肉眼的血尿は平均約 90 分で，また顕微鏡的血尿は平均約 180 分で消失した.

2）採取組織片の大きさは，長さ約 5 20 mm，幅約 1〜1. $5 \mathrm{~mm}$ で，多少の破壊や緶みを示すも のもあったが，診断に支障をきたすほどではなかった。事実，腎臓疾患群の牛で間質性腎炎および アミロイドーシスが確認された.

3）生検後 1〜10 日後に剖検した 13 例すべてにおいて, 腎臟の包膜と周囲組織との間に約 5〜 $100 \mathrm{ml}$ の血液を含有した血腫が認められた.

4）生検後の一般臨床観察および血液学的検査に打いて, 上記の一過性血尿を除いてとくに異常 は認められなかった。

腎蔵疾患の診断は，通常，一般臨床所見，尿所見およ び血液化学所見 (BUN，クレアチニン) などをもとにし て行われているが，早期に的確な病態を把握し，正確に 診断するのは困難なこと采が多い。

そこで, 腎蔵生検（以下，生検）により組織学的にも 検査し，各種検查と合わせて総合的に診断すると，より 的確な信頼ある成績が期待できる.

* 酪農学園大学酪農学部（北海道江別市文京台緑町）

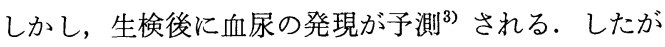
って, 生検実施後にみられる変化について, 血尿を主体 に経時的にその程度や継続時間を観察した．また，採取 組織片を病理組織学的検査に使用することが可能である かについても検討した.

\section{1. 供試材料と試験方法}

1）供試 牛

18 例のホルスタイン種乳牛を用いた. そのうち, 臨床

日獣会誌 $41 \quad 521 \sim 524 （ 1988 ）$ 


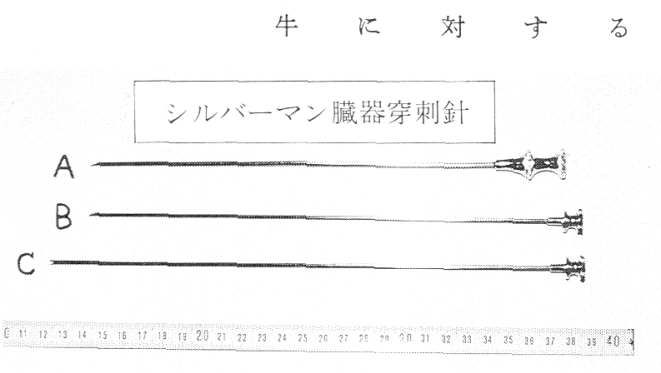

A：外套 B：マンドリン C：二叉針

写真 1 使用したシルバーマン臓器穿刺針

所見，尿および血液所見から腎臓疾患の疑われたもの3 例，腎臓疾患以外の疾患（乳房炎，肺炎，脳炎など） 10 例岕よび正常 5 例である.

\section{2) 生検 の方 法}

OSBORNE $5^{5)}$ の経皮的腎藏生検法に準拠し, これに若 干の工夫を付け加光て実施した。すなわら, 腎臓の解剖 学的位置を考虑し, 生検針の刺入は右膁部加らとし, 左 腎臓を採取目標臓器とした。 その概要は以下のとおりで ある。

（1）直腸検查により左腎臓の位置を左手で確かめ, 刺 入部位を決定し，その部位を剪毛し消毒する。

（2）保定は枠場保定とし, 必要に応じて尾椎硬膜外麻 酔および膁部の刺入部位の局所麻酔を行う。

(3) 消毒したシルバーマン臓器穿刺針 (全長約 $25 \mathrm{~cm}$ ) を腹腔内に刺大し，1人が左手を用いて直腸を介し，左腎 臓を右腹壁方向一移動させる，右手飞生検針を持ち，針 先の監臓表面への移動を試みる ${ }^{6)}$ 。生検針を通して伝わ る抵抗感，さらに腎臓を静かに動かすことによる生検針 の微かな動きにより針先が腎臓表面に到達していること がわかる、できるだけ腎藏後端の皮質のみに刺入するよ らに腎臓の刺入部位を選定し，他の1人がマンドリンと 2 叉針とを交換し，素早〈刺入して組織片を採取する5).

（4）採取した組織片は，10\% ホルマリン液の入った試 験管に入れ, 固定後は速やかに組織標本を作製(薄切し, $\mathrm{HE}$ 染色与る）し，鏡検する。

\section{3）術後の尿の観 察}

生検前の尿を前尿亡し, 生検直後, 30 分後, 60 分後, 90 分後, 120 分後, 150 分後, 180 分後拈よび 24 時間後 に採取した。血尿の性状の観察に際しては, 上述のよう に採取した尿について，东ず肉眼的に観察し，次いでそ れを遠沈して沈椬を顕微鏡的に観察した。血尿の程度は 尿の赤色調の色彩を基準に以下の 5 段階に分類した.

$$
\begin{aligned}
& \text { (一); まったく認められないもの } \\
& \text { (土); かららじて認めるもの } \\
& \text { (十); 明らかに認めるもの } \\
& \text { (十); かなり強く認めるもの } \\
& \text { (H)；著しく明瞭に認めるもの }
\end{aligned}
$$

また，顕微鏡的には，一視野中 $(10 \times 100)$ に観察され
留生検の影響

る赤血球の出現程度によって分類した。

\section{2. 試 験 成 績}

1）生検後の血尿所見

(1) 血尿の消失時間：供試牛 18 例に打ける術後の 肉眼的所見亡顕微鏡的所見の経時的な推移を図 1 亿示し た。肉眼的血尿は約 90 分で, また顕微鏡的血尿は約 180 分で消失した。

（2）各群における肉眼的血尿の観察：腎疾患群，その 他の疾患括よび正常群の 3 群にわけ, 術後の血尿の肉眼 的所見の推移を㝊た(図 2 )。午の結果，腎疾患群で血尿 の程度がとくに強く, 消失時間も延長していた。これに 次いでその他の疾患群のそれが強かった。いっぽう, 正 常群では肉眼的血尿はまったく観察されなからた。

（3）各群における顕微鏡的血尿の観察 : 各群の尿にり いて顕微鏡的血尿の推移をみたところ，腎疾患群に扣い

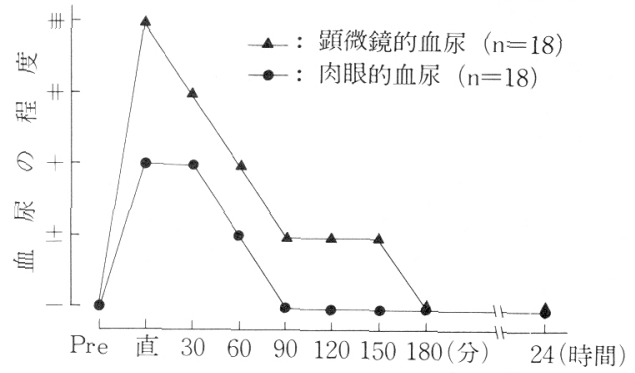

図 1 血康の経時的観察（平均値）

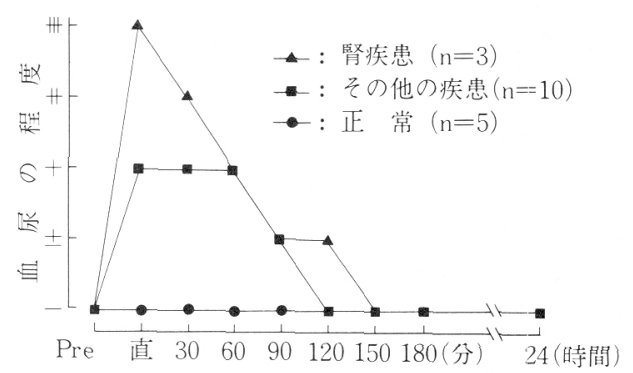

図 2 疾患別分類に上る肉眼的血尿の経時的観察 (平均値)

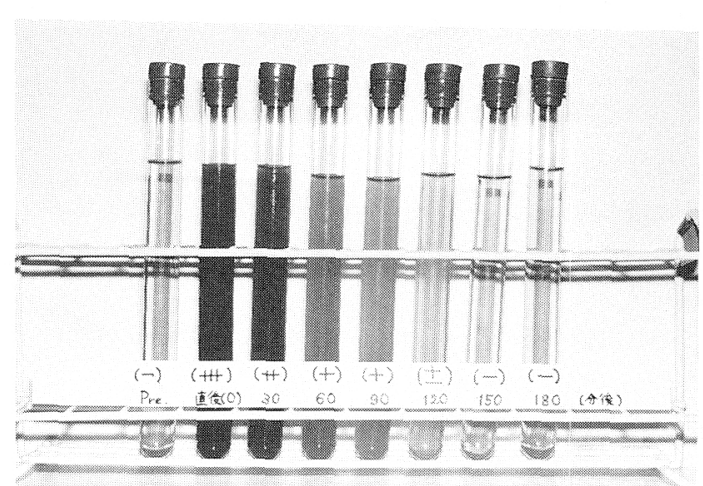

写真 2 生検後に新汀る肉眼的血尿の推移（腎炎牛） 


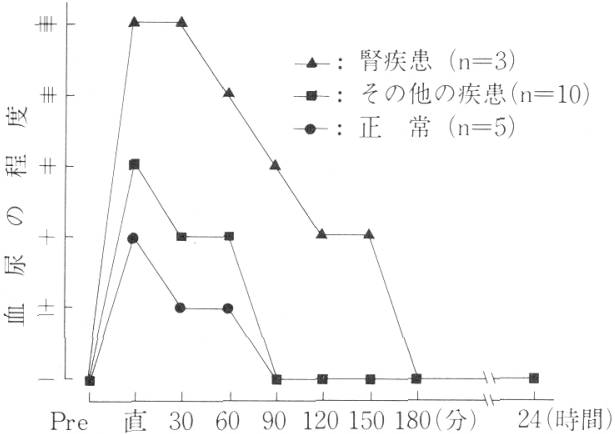

図3 疾患別分類に上る顕微鏡的血尿の経時的 観察 (平均値)

て血尿の程度が最も強く, 消失時間も延長していた。次 いでその他の疾患群执よび正常群という順序であった。 とくに, 正常群の尿所見では肉眼的には常に(一)であっ たのに対し，顕徵鏡的には直後において(十)であり，完 全な消失までに約 90 分を要した（図 3 ).

2）採取した組織片についての観察

(1) 組織片の大きさ：長さ約 5〜20 mm，幅約 1〜1.5 $\mathrm{mm}$ でやや透明感のある組織片として採取された。

(2) 生検組織の HE 染色所見：両側の破壞, 縮及, 特 よび系球体の脱落の起こっているものが多かった。し かし，いずれの例に括いても杀球体，間質および尿細管 などの病変の診断が不可能となるほどのものではなかっ た。

（3）腎炎が疑われた牛における生検所見：間質に細胞 浸潤执よび線維性組織の増生が顕著に認められ，間質性 腎炎であることが判明した。剖検後の組織像に括いても 同様の所見が得られた。

(4) アミロイドーシスが疑われた牛における生検所 見：糸球体毛細血管周囲にアミロイドの沈着が, また尿 細管腔にもアミロイド様物質の存在が観察された ${ }^{1,4)}$.ア ミロイド沈着の程度が本法の応用によって確認された。

3）生検後にみられた合併症

（1）生検後剖検した 13 例の所見：生検後 1〜10 日後 に剖検した 13 例の全例で, 腎灆の包膜と周囲組織との 間に種々の程度の血腫が観察された。气の含有血液の量 は, 多いもので約 $100 \mathrm{ml}$, また少ないもので約 $5 \mathrm{ml}$ で あった。腹腔内への出血, あるいは瘉着, 炎症などの観 察された例はなかった。

（2）生検前・後の臨床所見の推移：生検前, 生検後第 1 日, 生検後第 3 日扣よび生検後第 7 日に, 体温, 心拍 数, 呼吸数招よび可視粘膜を含めた一般臨床観察を行っ たが，とくに異常は認められなかった。

（3）生検前・後の血液所見の推移: Ht 値, 赤・白血球 数, 白血球百分比拈よび血清蛋白について臨床観察と同 様に観察した。その結果，とくに異常な変化は認められ

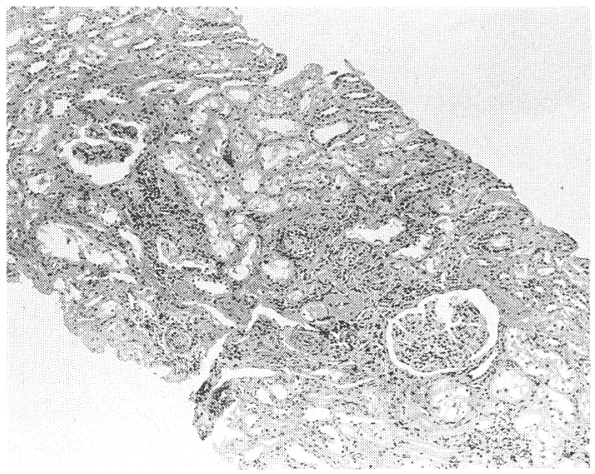

写真 3 生検組織で, 間質に細胞浸潤之線維 性組織の增成がみられる間質性腎炎 $(\mathrm{HE}$ 染色 $\times 350)$

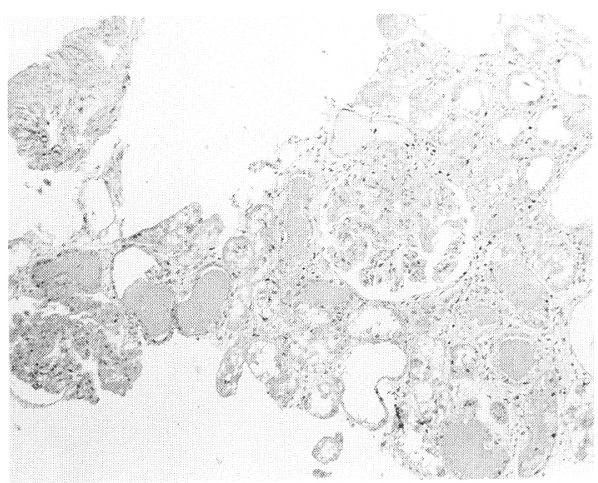

写真 4 生検組織で, 系球体にアミロイド沈着, 尿細管腔にアミロイド物質を含をアミロ イド腎 $(\mathrm{HE}$ 染色 $\times 380)$

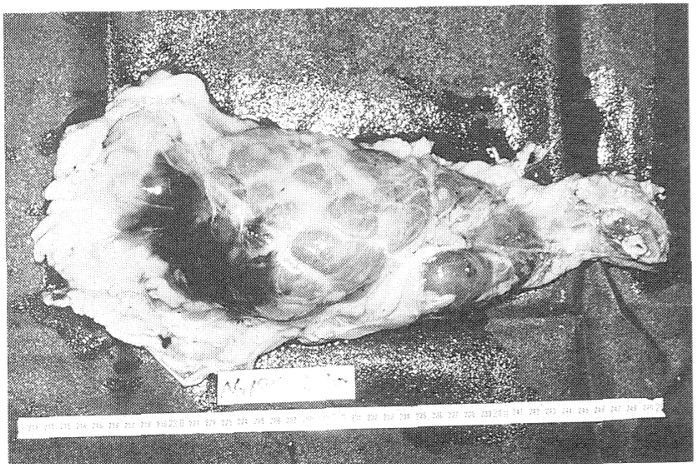

写真 5 生検後 7 日後に剖検された例の腎獩の 包膜と周囲組織との間の血腫

なかった。

\section{3. 考察}

腎生検後に認められた血尿は，肉眼的には約 90 分で 消失，影微鏡的には約 180 分で消失した。腎臓疾患群に 执いて肉跟的飞も顕微鏡的飞も血覀の程度が強く, かつ 
牛に 対 す る

消失までの時間に延長がみられた。このことは, 腎臓に なんらかの異常がある場合, 腎生検などの腎蔵実質損傷 時には健康な個体に比へ，腎臓実質が破壊されやすくな っているためではないかと推察される.

つぎに，採取された腎臟組織片の長さは約 $5 \sim 20 \mathrm{~mm}$ とまちまちであったが, このことは, 牛の腎㵴は葉状腎 で各分葉の大きさも多様であって, 直腸を介しての触診 ではそれらの確かな大きさを正確に感知し得ないこと， 生検針の刺入角度抢よび刺入の際の腎臓の固定具合など によるものと思われる. しかし， $5 \mathrm{~mm}$ 程度の組織片に おいて子注意して標本を作製すれば，顕微鏡的組織検査 は十分可能であった.

また，臨床的に腎炎と診断した例の生検で，糸球体腎 炎ではなく，間質性腎炎であることが明らかになった点 は, 生検の有効性を裏付汓るものである.アミロイドー シスの症例に执いても, アミロイドの沈着状態拉よび量 などが実際に顕微鏡下で観察され, 生検の有効性が示唆 された。

今回の供試牛のらち, 剖検した全例で生検の合併症と $し て$, 腎臓の包膜と周囲組織との間に約 $5 \sim 100 \mathrm{~m} l$ 程度 の血腫が観察された.しかし, 腹腔内への出血あるいは
癒着といった例は 1 例もなかった。また, 生検後の一般 臨床検査に打いても牛体にはとくに悪影響は認められな かった。このことから牛に和ける腎生検は診断手技とし て安全性の高いものと思われた.

\section{引用文献}

1) 藍沢茂雄, 浦野順文, 小森 亮, ほか：組織病理 アトラス, 174 193, 文光堂, 東京 (1985).

2) Deem, D. A., Tullener, E. P., Whitlock, R. H., et al.: J. Amer. Vet. Med. Ass., 179, 696 700 (1981).

3) Duncan, J. R., Whitlock, R. H., Divers, T. J., et al.: J. Amer. Vet. Med. Ass., 181, 694 699 (1982).

4) NaOI, M., Kokue, E., Takahashi, Y., et al.: Am. J. Vet. Res., 46, 699 702 (1985).

5) Mouwen, J.: A colour atlas of veterinary pathology, 高橋令治, 野村靖夫訳, $48 \sim 50$, 西村書店, 新渴 (1982).

6) Osborne, C. A., Schultz, R. H. and Perman, V.: J. Amer. Vet. Med. Ass., 153, 563 569 (1968).

7) Rosenberger, G.: 牛の臨床検查診断, 其田三夫, 河田啓一郎訳, 301 302, 近代出版, 東京 (1979).

\section{《海外文 献 要 録》}

免疫処置, 胸腺欠損および正常 BALB マウスに护ける Chlamydia trachomatis 肺炎像

Chlamydia trachomatis Pneumonia in the Immune, Athymic and Normal BALB Mouse

J. J. Coalson, V. T. Winter, L. B. Bass, J. Schachter, B. G. Grubis and D. M. Williams: Br. J. Exp. Pathol., 68, 399 411 (1987).

本論文は，マウス由来の C. trachomatisによる肺炎を， 感受性のある胸腺欠損 ードマウス，抵抗性であるへテ 口の同腹子扣よび強抵抗性である免疫処置マウスに打い て実験的に作出し, 病理組織学的に比較検討したもので ある.

これらすべての実験群のマウスは, 接種後初期には偽 好酸球反応を示したが, 宿主防御は多数の形質細胞, リ ンパ球，単球打よび脂肪貪食大食細胞の出現でなされて いた．網様小体はすべての群の, とりわけI型肺胞上皮 に見られた. 免疫処置群では, 接種後 24 時間まで菌体 は認められず, これは防御機序の早期の活性化とみなさ
れた．感染の至適対照群であるヌードマウス群では，急 速な経過を示したが，より多く出現した偽好酸球は防御 機序に対して効果がないよらであった.

本研究から, 免疫不全状態のマウスのクラミジア肺炎 の病理組織像は, 全く非定型的であり, 偽好酸球の反応 が優勢で, 単核細胞反応を欠くが菌体は見られること, 免疫マウスでは単核細胞は宿主防御として重要な役割を 演じ，形質細胞浸潤を伴った B 細胞の活性化は $\mathrm{T}$ 細胞機 能に依存していることが示された。

(日本獣医師会雑誌編集委員会) 